\title{
Peran Guru dan Masyarakat Sekolah Dalam Menghadapi Pengaruh Media Sosial Terkait dengan Kenakalan Remaja di SMA Negeri 1 Mauponggo
}

\author{
Gufran Sabarin', Achmad Djunaidi²
}

${ }^{1}$ Pendidikan Pancasila dan Kewarganegaraan, Universitas Muhammadiyah Mataram, gufransabarai32@gmail.com

${ }^{2}$ Pendidikan Pancasila dan Kewarganegaraan Universitas Muhammadiyah Mataram, djuanidiachmad@gmail.com

INFO ARTIKEL
Riwayat Artikel:
Diterima: $\quad$ 15-Agustus-
2018
Disetujui: $18-S e p t e m b e r-$
2018

Kata Kunci:

peran

guru

masyarakat

media sosial

kenakalan

\begin{abstract}
ABSTRAK
Abstrak: Arus globalisasi yang diikuti dengan perkembangan tekhnologi memberikan berbagai pengaruh yang cukup besar terhadap keadaan masyarakat, terutama pada kalangan remaja dapat membuat mereka berbuat positif maupun negatif. Penelitian ini bertujuan menggambarkan peran guru dan masyarakat sekolah dalam menghadapi pengaruh media sosial terkait dengan kenakalan remaja di SMA 1 Mauponggo dan usahausaha apakah yang dilakukan pihak sekolah dalam menanggulangi kenakalan remaja tersebut. Metode penelitian ini menggunakan kualitatif dengan pendekatan deskriptif. Teknik pengumpulan data menggunakan observasi, wawancara, dan dokumentasi. Informan kunci dalam penelitian ini adalah kepala sekolah, guru dan siswa. Data yang sudah terkumpul dianalisis melalui langkah-langkah reduksi data, penyajian data dan menarik kesimpulan. Hasil penelitian menunjukkan bahwa peran guru akan senantiasa menggambarkan pola tingkah laku yang diharapkan dalam berbagai interaksinya, baik dengan siswa, sesama guru, maupun mengajar, dapat dipandang sebagai sentral bagi peranannya. Sebab baik disadari atau tidak bahwa sebagian dari waktu dan perhatian guru banyak dicurahkan untuk mengkaji proses belajar mengajar dan berinteraksi dengan siswanya. Peran guru dalam proses belajar mengajar adalah guru sebagai pendidik, guru sebagai pengajar dan fasilitator, guru sebagai pembimbing, guru sebagai pengarah, guru sebagai pelatih, guru sebagai penilai, guru sebagi pemimpin, guru sebagai mediator, dan guru sebagai evaluator.
\end{abstract}

\begin{abstract}
The current of globalization which is followed by the development of technology provides a considerable amount of influence on the condition of society, especially among adolescents can make them do positive and negative. This study aims to describe the role of teachers and school community in dealing with the influence of social media related to juvenile delinquency in Mauponggo 1 High School and what efforts have been made by the school to overcome the juvenile delinquency. This research method uses qualitative with a descriptive approach. The technique of collecting data uses observation, interviews, and documentation. Key informants in this study were principals, teachers and students. Data that has been collected is analyzed through steps of data reduction, data presentation and drawing conclusions. The results of the study indicate that the role of the teacher will always describe the expected patterns of behavior in various interactions, both with students, fellow teachers, and teaching, can be seen as central to their role. Because whether it is realized or not, a portion of the teacher's time and attention is devoted to studying the learning process and interacting with students. The role of the teacher in the teaching and learning process is the teacher as an educator, the teacher as the teacher and facilitator, the teacher as the guide, the teacher as the director, the teacher as the trainer, the teacher as the assessor, the teacher as the leader, the teacher as the mediator, and the teacher as the evaluator.
\end{abstract}

\section{A. LATAR BELAKANG}

Media sosial telah menjadi suatu kebutuhan bagi seluruh lapisan masyarakat, dari berbagai tingkatan usia, jenis kelamin, pendidikan maupun tempat tinggal. Selain itu, media juga sebagai sarana penunjang bagi manusia untuk memenuhi kebutuhan komunikasi, informasi serta hiburan. Perkembangan dunia teknologi yang semakin cepat dan dinamis membuat banyak sekali perubahan dalam kehidupan, termasuk perubahan dalam penggunaan media komunikasi. Internet salah satunya, jika dulu orang harus menggunakan media surat untuk berkomunikasi jarak jauh maka sekarang cukup dengan Smartphone dengan internet orang dapat mudah saling bertukar kabar. Berbagai macam aplikasi messenger yang mulai bermunculan seperti, skype, blackberry messenger, Yahoo Messenger, facebook, twitter, path, instagram, Whats App, Youtube, dan line semakin mempermudah komunikasi antar manusia.

Dampak dari perkembangan media sosial ini baik dampak positif maupun negatif terhadap remaja, terlebih lagi pada dampak yang membuat perubahan 
sosial pada remaja. Sebagian masyarakat kita di setiap rumah baik di kota bahkan sampai ke desa-desa selalu menghadirkan berbagai bentuk hasil karya teknologi tersebut sebagai bagian kelengkapan bagi penghuni rumahnya. Hasil karya teknologi komunikasi dan informasi seperti media sosial dapat membuat seorang remaja menjadi mengubah pola hidup, mendatangkan kebiasaan-kebiasaan baru, bahkan dikatakan bahwa kebutuhan akan teknologi sebagai bentuk orang hipnotis canggih yang mampu mengubah perilaku dan cara mereka berkomunikasi dengan orang lain[1].

Remaja dengan berbagai macam masalahnya tentu saja memunculkan berbagai perilaku. Sebagian dari perilaku tersebut bisa berupa kenakalan remaja. Kenakalan remaja mengacu kepada suatu rentang perilaku yang sangat luas, mulai dari perilaku yang tidak dapat diterima secara sosial, pelanggaran, hingga tindakan kriminal[2]. Salah satu bentuk kenakalan remaja adalah dalam hal perilaku tawuran antar pelajar, pembunuhan, penipuan, trafficking dan kebebasan seks, dan lain-lain. Akhir-akhir ini semakin banyak ditemukan kasus mengenai dengan kenakalan remaja. Bahkan hal ini sudah terjadi sejak dulu, kenakalan remaja bagaikan fenomena gunung es yang terus berlanjut, semakin ditelisik semakin kompleks permasalahnya. Sejalan dengan arus globalisasi dan teknologi yang semakin berkembang, arus informasi yang semakin mudah di akses serta gaya hidup modernisasi, disamping memudahkan dalam mengetahui berbagai informasi di media, di sisi lain juga membawa suatu dampak2negatif yang cukup meluas di berbagai lapisan masyarakat.

Berikut ini diuraikan data peningkatan kenakalan remaja dari tahun ke tahun diambil dari badan pusat statistik (BPS) di Kabupaten Nagekeo, pada tahun 2014 angka kenakalan remaja di Kabupaten Nagekeo mencapai 38 kasus, sedangkan pada tahun 2015 jumlahnya mencapai 40 kasus dan pada tahun 2016 mencapai 99 kasus. Artinya dari tahun 2014-2015 mengalami kenaikan sebesar $1,0 \%$, sedangkan dari tahun 2015-2016 mengalami kenaikan sebesar 2,4 \%. Kasus tersebut terdiri dari berbagai kasus kenakalan remaja diantaranya, pencurian, pembunuhan, pergaulan bebas dan narkoba. Dari data tersebut kita dapat mengetahui pertumbuhan jumlah kenakaln remaja yang terjadi tiap tahunya. Dari data yang tertera diatas dapat diprediksi jumlah peningkatan angka kenakalan remaja dari tahun 2014-2015 mengalami kenaikan 1,0 \%, sedangkan pada tahun 2015-2016 mengalami kenaikan sebesar 2,4 \%. Sehingga perbandingan kenakalan remaja dari tahun ke tahun mengalami kenaikan sebesar 2,4 \%.

Untuk mengatasi hal tersebut perlu suatu perhatian dari berbagai kalangan, peran dari masyarakat sangatlah diharapkan terutama dari masyarakat sekolah itu sendiri. Mengingat sekolah adalah salah satu dari Tri Pusat Pendidikan yang menjadi alternatif kedua yang sangat berperan penting dalam mentransfer nilai di dalam diri siswa. Hal yang demikian perlu dilakukan sebuah revitalisasi terhadap perilaku dan moral remaja. Untuk itu dalam melakukan sebuah perubahan terhadap hal yang demikian maka perlu adanya sebuah jembatan yang dapat dijadikan sebagai suatu jalan agar dapat tercapainya suatu tujuan yang diharapkan. Yang dimana sesuatu yang dapat menjadi jembatan sebagai penyalur nilai terhadap remaja adalah peran dari masyarakat sekolah itu sendiri.

Guru memiliki tanggung jawab besar dalam menghasilkan generasi yang berkarakter, berbudaya, dan bermoral. Dewasa ini, tuntutan dan peran guru semakin kompleks, tidak sekedar sebagai pengajar semata, pendidik akademis tetapi juga merupakan pendidik karakter, moral dan budaya yang berlaku di Indonesia. Guru diharapkan menjadi model dan teladan bagi anak didiknya dalam mewujudkan perilaku yang berkarakter yang meliputi olah pikir, olah hati dan olah rasa. Untuk mewujudkan manusia Indonesia yang berkarakter kuat[3]. Orangtua (ibu) dan keluarga lain (kakek, nenek, bibi, paman) yang berperan dalam keseharian anak dalam membangun karakter siswa, sehingga mampu mengcover semua lapisan siswa korban[4].

Pendidikan berbasis masyarakat merupakan pendidikan yang sebagian besar keputusan kependidikannya ditentukan oleh masyarakat, mulai dari masalah input, proses dan output pendidikan, hingga masalah pendanaan. Sebuah model yang dapat dijadikan contoh bagi pendidikan berbasis masyarakat adalah lembaga pesantren atau lembaga pendidikan non formal yang memiliki kurikulum sendiri, mengusahakan pendanaan sendiri dan melayani kebutuhan masyarakatnya sendiri[5].

Pemanfaatan yang media social adalah untuk tujuan positif meskipun dalam prakteknya Internet digunakan juga untuk tujuan negatif oleh sebagian kecil pengguna Internet. Beberapa new media di Internet seperti situs jejaring sosial dan situs berbagi video sering kali mempengaruhi gaya hidup pengguna Internet dan bukan hanya itu, materi yang diunggah ke kedua media itu juga mudah sampai ke masyarakat luas misalnya melalui telepon genggam yang sebagian besar masyarakat sudah memilkinya[6].

Penggunaan media social dapat merasa gembira menggunakan laman sosial berkenaan di samping memperolehi maklumat semasa. Dalam konteks perhubungan dengan anak-anak, terdapat sebahagian responden yang mengakui bahawa media sosial berpontesi menjadi pemantau aktiviti anak-anak[7]. Dengan demikian maka berdasarkan penelitian yang telah dilakukan adapun tujuan yang diuraikan dalam artikel ini adalah menggambarkan peran guru dan masyarakat sekolah dalam menghadapi pengaruh media sosial terkait dengan kenakalan remaja di SMA 1 Mauponggo dan usaha-usaha apakah yang dilakukan pihak sekolah dalam menanggulangi kenakalan remaja tersebut. 


\section{B. METODE PENELITIAN}

1. Metode penelitian yang Digunakan

Penelitian ini menggunakan metode kualitatif dengan pendekatan deskriptif yang bertujuan untuk mendapatkan data tentang peran guru dalam menghadapi pengaruh media sosial terkait dengan kenakalan remaja, yaitu berusaha menggambarkan fakta dan kenyataan sosial kemudian dianalisis dengan menggunakan pengetahuan, ide-ide, konsep yang ada dalam SMA 1 Mauponggo kabupaten nagekeo.

Metode penelitian kualitatif adalah metode panelitian yang melandaskan pada filsafat postpositivisme, digunakan untuk meneliti pada kondisi objek yang alamiah, dimana peneliti sebagai instrument kunci, teknik pengumpulan data dillakukan secara trianggulasi (gabungan), analisis data bersifat induktif/kualitatif, dan hasil penelitian kualitatif lebih menekankan Makna dari pada generalisasi[8]. Metode kualitatif ini digunakan karena beberapa pertimbangan diantaranya adalah sebagai berikut[9]:

a. Menyesuaikan metode kualitatif lebih mudah apabila berhadapan dengan kenyataan langsung (jamak).

b. Metode ini menyajikan secara langsung hakikat hubungan antara peneliti dan responden.

c. Metode ini lebih peka dan lebih dapat menyesuaikan diri dengan banyak penajaman pengaruh bersama terhadap pola-pola nilai yang dihadapi.

Dari beberapa pernyataan diatas maka dapat disimpulkan bahwa penelitian ini menggunakan penelitian kualitatif dengan menggunakan pendekatan deskriptif yaitu menjelaskan atau mendeskripsikan gejalah yang telah ada dan sedang berlangsung. Ada pun tujuan penggunaan metode penelitian kualitatif adalah untuk memperoleh informasi mengenai peran guru dan masyarakat sekola dalam menghadapi pengaruh media sosial terkait dengan kenakalan remaja di SMA 1 mauponggo kecamatan mauponggo kabupaten nagekeo.

\section{Lokasi Penelitian}

Penelitian ini menggunakan rancangan histografi (ilmu sejarah) adalah fenomena pendidikan tentang perang guru dalam menghadapi pengaruh media sosial terhadap remaja. Penelitian ini dilaksanakan di SMA 1 mauponggo keamatan mauponggo kabupaten nagekeo. Alasan pemilihan lokasi penelitian karena salah satu sekolah diwilayah kabupaten Nagekeo yang suda terjerat oleh pengaruh media sosial, sehingga siswa maupun siswi sudah berani melakukan hal-hal yang negatif, sperti tawuran antar pelajar, menggunakan obat-obat terlarang, pacaran, maupun pemerkosaan. Untuk itu penulis ingin menerapkan nilai strata yang membantu menambah wawasan bagi remaja sekitar.

3. Subjek Penelitian
Dalam penelitian kualitatif tidak menggunakan istila populasi, tetapi Spradley dinamakan social situation atau situasi sosial yang terdiri dari tiga elemen yaitu: tempat, pelaku, dan aktivitas yang berinteraksi secara sinergis.

Dalam penelitian kualitatif tidak menggunakan populasi, karena penelitian kualitatif berangkat dari kasus tertentu yang ada pada situasi sosial tertentu dan hasil kajiannya tidak akan diberlakukan kepopulasi tetapi ditransferkan ke tempat lain pada situasi sosial pada kasus yang dipelajari. Sampel dalam penelitian kualitatif bukan dinamakan responden, tetapi narasumber atau partisipan, informan, teman dan masyarakat dalam penelitian[10].

Dalam penelitian kualitatif tekhnik sampling yang digunakan adalah purposive sampling dan snowballsampling. Purposive sampling adalah tekhnik pengambilan sampel sumber data dengan pertimbangan tertentu. Snowball sampling adalah tekhnik pengambilan sampel sumber data yang pada awalnya jumlahnya sedikit lama-lama menjadi besar[11].

Berdasarkan hal tersebut di atas bahwa, penentuan teknik sampel dalam penelitian menggunakan teknik purposive sampling, jika data yang diperoleh teknik ini masih kurang maka akan digunakan snowballsampling. Digunakan tekhnik purposive sampling ini karena informasi ini dianggap lebih tahu dan paham terhadap masalah yang diteliti dan dapat memberikan data yang lebih lengkap, mereka itu adalah kepala sekolah, guru PPKn, guru BK dan siswa pada umumnya. Sedangkan tekhnik snowball sampling ini digunakan karena data yang diperoleh dari informan sebelumnya dirasakan belum sempurna atau masih kurang untuk itu dilakukan penambahan terhadap informan agar data yang diambil sesuai dengan target dan harapan dalam pelaksanaan penelitian yaitu sampai data jenuh (Maksudnya kalau data sudah tidak bisa digali lagi atau jawaban responden akhirnya hanya berputar ke itu-itu saja).

\section{Tehnik Penentuan Informan}

Dalam penelitian kualitatif tidak menggunakan istilah populasi, tetapi menggunakan teknik penentuan informan. Informan adalah orang yang dimanfaatkan untuk memberikan informasi tentang kondisi latar penelitian, jadi ia harus mempunyai banyak pengalaman tentang latar penelitian[12]. Dalam penelitian ini, penentuan informan dilakukan dengan cara purposive sampling.

Purposive sampling adalah tehnik pengambilan sampel sumber data dengan pertimbangan tertentu. Pertimbangan tertentu ini misalnya orang tersebut yang dianggap paling tahu tentang apa yang kita harapkan, atau mungkin ia sebagai penguasa sehingga akan memudahkan peneliti menjelajahi objek/situasi sosial yang akan diteliti[9].

Jadi dapat disimpulkaan dari beberapa kriteria di atas bahwa penelitian kualitatif engan menggunakan 
porposive sampling merupakan teknik pengumpulan data dengan cara pertimbangan tertentu yaitu orangorang yang memahami tentang pengaruh media sosial terhadap remaja sekolah SMA 1 Mauponggo, seperti kepala sekolah SMA 1 Mauponggo, para guru SMA 1 Mauponggo.

5. Metode Pengumpulan Data

a. Teknik Observasi

Observasi adalah dasar semua ilmu pengetahuan[13]. Sedangkan Marshall melalui observasi peneliti belajar tentang prilaku, dan makna dari perilaku tersebut. Para ilmuwan hanya dapat bekerja berdasarkan data, yaitu fakta mengenai dunia kenyataan yang diperoleh melalui observasi[8].

Dari dua pendapat di atas dapat disimpulkan bahwa observasi adalah pengamatan secara langsung terhadap objek yang diteliti berupa hal-hal yang tampak dan melakukan pengamatan terhadap aktivitas-aktivitas yang sedang berlangsung terhadap sesuatu yang diteliti kemudian dideskripsikan dalam bentuk tulisan oleh peneliti. Sehingga peneliti sangat mudah untuk mengolah dan menganalisa data hasil observasi tersebut.

Dalam penelitian ini, peneliti hanya menggunakan dua jenis observasi yaitu:

1) Observasi terus terang atau tersamar

Dalam hal ini peneliti dalam melakukan pengumpulan data menyatakan terus terang kepada sumber data, bahwa Ia sedang melakukan penelitian. Jadi mereka yang diteliti mengetahui sejak awal sampai akhir tentang aktifitas peneltian. Tetapi dalam suatu saat peneliti juga tidak terus terang atau tersamar dalam observasi, hal ini untuk menghindari kalau suatu data yang dicari merupakan data yang masih dirahasiakan. Kemungkinan kalau dilakukan dengan terus terang, maka peneliti tidak akan diijinkan akan melakukan observasi.

2) Observasi tak berstruktur

Observasi dalam penelitian kualitatif dilakukan dengan tidak berstruktur, karena fokus penelitian belum jelas.fokus observasi akan berkembang selama kegiatan observasi berlangsung.

Dalam kegiatan observasi yang diobservasikan oleh peneliti adalah pendidikan, terutama yang berkaitan dengan peran guru dan masyarakat sekolah dalam menghadapi pengaruh media sosial terhadap remaja di SMA 1 Mauponggo Kec Mauponggo Kab Nagekeo.

\section{b. Teknik Wawancara}

Wawancara adalah pertemuan dua orang untuk bertukar informasi dan ide melalui tanya jawab, sehingga dapat dikonstruksikan makna dalam suatu topik tertentu[14]. Wawancara digunakan sebagai teknik pengumpulan data apabila peneliti ingin melakukan studi pendahuluan untuk menemukan permasalahan yang harus diteliti, tetatpi juga apabila peneliti ingin megetahiu hal-hal dari responden yang lebih mendalam.

Berdasarkan pengertian di atas dapat disimpulkan bahwa wawancara adalah hubungan antara dua orang yang saling berinteraksi dalam arti bertukar pikiran untuk memperoleh ide melalui proses tanya jawab.

Wawancara tak berstruktur adalah wawancara yang bebas dimana peneliti tidak menggunakan pedoman wawancara yang telah tersusun secara sistematis dan lengkap untuk pengumpulan datanya. Pedoman wawancara yang digunakan hanya berupa garis-garis besar permasalahan yang akan ditanyakan. Dalam wawancara tidak berstruktur peneliti belum mengetahui secara pasti data apa yang akan diperoleh, sehingga peneliti lebih banyak mendengarkan apa yang diceritakan oleh responden.

\section{c. Teknik Dokumentasi}

Dokumentasi merupakan catatan peristiwa yang sudah ada. Dokumen bisa berupa tulisan, gambar atau karya-karya monumental dari seseorang. Dokumen yang berbentuk tulisan misalnya catatan harian, sejarah kehidupan, ceritera, biografi, peraturan, sedangkan dokumen yang berbentuk gambar misalnya foto, gambar hidup, sketsa dan lain-lain[9].

Berdasarkan teorinya Sugiyono di atas dapat disimpulkan bahwa dalam tehnik dokumentasi ini peneliti akan menggunakan, foto, catatan atau data-data berupa tulisan tentang kepalah sekolah masyarakat sekolah dan siswa/i SMA 1 Mauponggo. Data yang dikumpulkan berupa foto pengajaran oleh guru terhadap siswa didalam kelas.

\section{Teknik Analisis Data}

Adapun metode analisis data yang akan digunakan adalah sebagai berikut[15];[8]:

\section{a. Reduksi data (data reduction)}

Digunakan untuk menarik kesimpulan dari beberapa data yang bersifat umum. Data-data yang bersifat khusus yang diperoleh dalam penelitian ini akan diolah supaya dalam penyajiannya akan menghasilkan generalisasi.

Data yang diperoleh dari lapangan jumlahnya cukup banyak, untuk itu maka perlu dicatat secara teliti dan rinci. Seperti telah dikemukakan, semakin lama peneliti ke lapangan, maka jumlah data akan semakin banyak, kompleks dan rumit. Untuk itu perlu segera dilakukan analisis data melalui reduksi data. Mereduksi data berarti merangkum, memilih hal-hal yang pokok, memfokuskan pada hal-hal yang penting, dicari tema dan polanya. dengan demikian data yang telah akan memberikkan gambaran yang lebih jelas, dan mempermudah peneliti untuk melakukan pengumpulan data selanjutnya, dan mencarinya bila diperlukan.

b. Penyajian data (data display)

Digunakan untuk menarik kesimpulan dari beberapa data yang bersifat umum menjadi kesimpulan yang bersifat khusus. Data yang bersifat umum yang diperoleh dari informan akan diolah sesuai dengan spesifikasi yang terdapat dalam batasan masalah baik tempat, waktu, ataupun tema sehingga data-data tersebut sesuai dengan tujuan penelitian yang ingin dicapai oleh peneliti. 


\section{c. Menarik Kesimpulan}

Menarik kesimpulan atau vertifikasi data dalam rangka memuat kesimpulan hasil penelitian yang dituang dalam pembahasan. Setelah data direduksi dan disajikan maka dilakukan kesimpulan tentang peran guru dan masyarakat sekolah dalam menghadapi pengaruh media sosial terkait dengan kenakalan remaja.

\section{HASIL DAN PEMBAHASAN}

\section{Peran Guru dalam Menghadapi Pengaruh Media Social}

Peran guru dalam membimbing peserta didik agar lebih bijak dalam menggunakan situs jajaring sosial atau media sosial sangat dibutuhkan. Hal ini menjadi penting dikarenakan pada saat ini hampir semua orang menggunakan media masa sebagai kebutuhan sahari hari. Tidak berbeda oarang orang dewasa yang menggunakan media sosial untuk kepentingan kerja atau kepentingan keluarga, anak anak atau remaja atau pelajar turut menggunakan media sosial untuk memenuhi kebutuhan mereka.

Guru sebagai pendidik sekaligus orang tua peserta didik disekolah harus mengetahui perkembangan peserta didik baik perkembangan sosial maupun lainnya. Siswa yang menggunakan aplikasi media sosial seringnya lupa waktu, saat proses belajar mengajar dalam kelas anak yang sudah ketergantungan dengan media sosial lebih sering menggunakan hanphonenya dari pada memperhatikan guru yang sedang menerangkan. Hal itu akibat kurangnya perhatian pendidik dalam mengevaluasi siswa pada saat kegiatan belajar mengajar.

Hasil penelitian berdasarkan keterangan informan Alosius Angi selaku kepala sekolah, beliau menayatakan:

"Memberikan pemahaman kepada siswa tentang pengaruh penggunaan jejaring sosial melalui layanan informasi, melakukan pencegahan terhadap dampak jejaring sosial, melakukan pengentasan masalah penggunaan jejaring sosial, dan melakukan pemeliharaan dan pengembangan dari penggunaan jejaring sosial yang berdampak positif'.(Wawancara, 28 april 2018).

Hal ini sejalan dnegan pernyataan Ibu Ana Nias Coo, selaku guru PPKn tentang peran ibu sebagai seorang pendidik, beliau menerangkan:

"Sebagai seorang pendidik, saya berperan penting untuk mendidik siswa agar menjadi manusia yang bermoral dan berkarakter mulia. Upaya saya dalam mendidik terkait dengan pengaruh media sosial yaitu dengan mengaitkan antara pembelajaran dengan kehidupan seharihari". (Wawancara, 1 Mei 2018)

Sedangkan menurut Ibu Nur Asfur selaku guru bahasa Indonesia, juga mengemukakan tentang peran ibu sebagai seorang penasehat, beliau menjelaskan:
"Sebagai seorang guru saya diharuskan dan diwajibkan untuk menasehati siswa dalam berbagai bentuk aktifitas dan kegiatan siswa. Pengaruh media sosial sekarang sangat memberikan dampak yang buruk apa biala tidak diimbangi dengan memberikan nasehat agar kehidupan siswa tetap berjalan pada norma kehidupan". (Wawancara, 8 Mei 2018)

Sebagai seorang pendidik, untuk mendidik siswa agar terhindar dari pengaruh media tersebut. Menurut Bapak Muhamad Saiful selaku guru PAI, beliau menjelaskan:

"Sebagai pendidik tentunya saya berusaha untuk mentransferkan nilai kepada siswa terutama nilai-nilai yang berkaitan dengan religiusitas. Saya selaku guru agama mencoba memberikan sebuah penanaman akan nilai-nilai agama yang harus dimilki oleh siswa terutama pada era tekhnologi saat ini. Tentunya didikan yang pernah diberikan agar siswa menjadi insan yang berakhlak mulia dan bermanfaat bagi orang lain". (Wawancara, 11 Mei 2018)

Hal serupa juga dijelaskan oleh bapak Wildan selaku guru BK/BP mengenai dengan peran bapak sebagai seorang penasehat, beliau menyatakan bahwa :

"Sebagai seorang guru, tentu saya harus menasehatin siswa-siswa yang bermasalah, karena ini adalah tugasnya saya sebagai guru BK. Dan saya akan berusaha untuk terus menasehatin siswa yang bermasalah, supaya mereka sadar dan tidak mengulangi kesalahannya". (Wawancara 15 Mei 2018)

Berdasarkan uraian penjelasan di atas maka disimpulkan bahwa peran guru sangat diperlukan dalam menghadapi pengaruh media sosial terkait dengan kenakalan remaja. Sebagai calon tenaga pendidik atau guru sudah seharusnya kita mengetahui bagaimana cara untuk memberikan perhatian dan penanganan yang sesuai dengan tahap tumbuh kembang anak. Hal ini dimaksudkan agar anak didik kita dapat tumbuh dan berkembang sesuai dengan yang kita harapkan dan bisa menjadi generasi bangsa yang unggul. Ciri generasi bangsa yang unggul salah satunya yaitu dengan menguasai ilmu pengetahuan dan teknologi yang dapat memanfaatkannya dengan bijak.

\section{Pengaruh media sosial terhadap kenakalan remaja}

Munculnya berbagai bentuk kenakalan yang dilakukan atau terjadi dikalangan remaja di SMA Negi 1 Mauponggo tersebut yang disebapkan oleh pengaruhnya media sosial. Faktor-faktor kenakalan siswa perlu diungkap secara jelas sehingga memudahkan dalam pembinaan dan pencegahannya. terkait tentang hal ini perlu dilakukan penelusuran informasi terutama pada Kepala Sekolah, guru PPKn, Guru Bahasa Indonesia, 
Guru PAI, Guru BK/BP, dan siswa yang bersangkutan terkait dengan tindak kenakalan remaja di sekolah.

Dari hasil wawancara dengan Kepala Sekolah, guru PPKn, Guru Bahasa Indonesia, Guru PAI, Guru BK/BP, dan siswa siswi yang bersangkutan diperoleh sejumlah informasi tentang faktor kenakalan remaja yang disebabkan oleh media sosial.

Hasil penelitian yang disampaikan Bapak Aloisius Anggi selaku kepala sekolah menyatakan:

"Yang pertama sangat berpengaruh pada media sosial, dikarenakan banyak siswa/i yang menggunakan media sosial kearah yang tidak baik, akibatnya siswa tidak terkontrol dengan perbuatannya yang merusak dirinya sendiri, sehingga menyebapkan kenakalan yang dilakukan oleh siswa itu sendiri, seperti pacaran di sekolah, bolos sekolah hanya untuk main-main ke starnet. Kedua, faktor keluarga juga bisa karena kurang disiplin, sebenarnya antara sekolah dan keluarga harus sejajr atau seimbang dalam mendidik anak, ketika di sekolah mengajarkan ahlak yang baik di rumah juga harus mendukung agar siswa tersebut bisa terkontrol oleh guru maupun orang tua." (Wawancara, 28 April 2018)

Muncul faktor faktor penyebab kenakalan siswa di SMA Negeri 1 Mauponggo, pada dasarnya munculnya pengaruh media sosial yang sudah merasuki pemikiran siswa, dan perilaku menyimpang atau kenakalan remaja itu sebenarnya merupakan kompensasi dari segala kekurangan dan kegagalan yang dialaminya dalam melakukan tugas perkembangannya termasuk dalam menjalin hubungan dengan lingkungan sosialnya (keluarga, sekolah dan masyarakat).

Menurut Ibu Ananias Coo selaku guru PPKn mengenai kaitannya dengan faktor kenakalan siswa yang disebapkan oleh media sosial bahwa:

"Penggunaan media sosial yang tidak baik bisa menyebapkan pemikiran oleh siswa itu sendiri menjadi nakal, dan juga menggunakan media sosial dengan mengapdet film porno dan fotofoto yang tidak sopan. Faktor pergaulan juga bisa menyebapkan siswa itu menjadi nakal, faktor keingintahunya saat masuk pada usia remaja dan tidak akan bosan-bosan menggunakan media sosial itu sendiri".

(Wawancara, 1 Meil 2018)

kondisi lingkungannya kurang kondusif dalam mendukung proses tugas perkembangannya, sehingga keluarga kurang memperhatikan pergaulannya anaknya.

Kejadian dan perilaku yang sering pada kenakalan remaja cukup beragam. Menurut Ibu Nur Asfur selaku guru Bahasa Indonesia menjelaskan:

"Ada beberapa masalah yang sering kami temui dalam kegiatan pembelajaran di sekolah terkait dengan kenakalan remaja yang disebabkan oleh pengaruh media sosial diantaranya ialah kurangnya minat belajar pada siswa, siswa lebih senang menyendiri dibanding berinteraksi dengan temanya" (Wawancara, 8 Mei 2018.)

Sedangkan menurut bapak Muhamad Saiful selaku guru PAI, beliau mengemukakan masalah yang sering bapak temukan pada siswa terkait dengan pengaruh yang ditimbulkan media sosial yang berhubungan dengan kenakalan remaja. Ia menjelaskan:

"Ada beberapa masalah yang sering saya temukan pada siswa terkait dengan kenakalan remaja yang dipengaruhi oleh media sosial diantaranya adalah minat belajar siswa semakin menurun, hal demikian dikarenakan siswa lebih banyak menghabiskan waktu dengan media sosial dibandingkan dengan belajar". (Wawancara, 11 Mei 2018)

Menurut bapak Wildan selaku guru BK/BP, beliau juga menjelaskan :

"Ada begitu banyak masalah yang kami temukan di sekolah ini yang disebapkan pengaruhnya media sosial, seperti membawa HP ke sekolah dan menonton film-film porno, pacaran yang berlebihan sehingga menyebapkan hamil diluar nikah". (Wawncara, 15 Mei 2018)

Kenyataan tersebut diatas terungkap pada temuan penelitian di SMA Negeri 1 Mauponggo, bahwa dari penuturan siswa yang bermasalah atau memiliki kasus tindak kenakalan di sekolah seperti bolos sekolah, tidak sekolah tanpa ada keterangan. Alasanya karna mereka malas dan mereka melakukan hal ini adalah karna mengikuti dan dipengaruhi teman

Lain halnya jikaa dilihat dari sisi siswa yang terkena kasus kenakalan di sekolah. Dari hasil waawancara dengan dua orang siswa tentang faktor media sosial yang menyebap atau yang melatar belakangi dirinya melakukan tindakan kenakalan di sekolah seperti yang dituturkan berikut ini:

"Salah satu adalah siswa di sekolah tersebut menceritakan permasalahannya, mengapa dirinya merokok, dan tawuran antar pelajar. Ia menjelaskan saya melakukan itu karena saya terpengaruh dengan media sosial,ikut sama teman-teman yang merokok dan suka berantam. Dan tidak terlepas pula saya bersama dengan teman-teman membolos sekolah hanya untuk duduk di starnet". (Wawancara, 5 Mei 2018)

Berdasarkan hasil penelitian pada dasarnya kenkalan remaja di SMA Negeri 1 Mauponggo disebabkan oleh pengaruhnya media sosial yang sudah merasuki pemikiran siswa itu untuk melakukan tindakan kenakalan. Dan ada juga faktor utama, yaitu faktor internal pada diri siswa itu sendiri, dan faktor eksternal dalam hal ini faktor lingkungan keluarga dan faktor lingkungan sosial (pergaulan). Faktor internal pada diri siswa itu bersumber pada kurang disiplinnya diri dan rendahnya motifasi belajar, serta ketidakmampuan diri dalam memecahkan masalah. 
Dari papaaran data di atas dapat disimpulkan bahwa pada dasarnya kenakalan remaja di SMA Negeri 1 Mauponggo disebapkan atau ditimbulkan oleh media sosial, sehingga banyak siswa yang melakukan tindakan kenakalan yang menentang dengan ketentuan sekolah dan bisa merusak dirinya sendiri.

Ada faktor lain yang menyebapkan kenakalan remaja, yaitu Faktor internal pada diri siswa itu sendri, dan faktor eksternal dalam hal ini faktor lingkungan keluarga, dan faktor lingkungan sosial (pergaulan). Faktor internal pada diri siswa itu bersumber pada kurangnya disiplinnya diri dan rendahnya motivasi belajar, serta ketidak mampuan diri dalam memecahkan masalah. Sedangkan faktor eksternal dalam hal ini lingkungan keluarga, dan faktor lingkungan sosial (pergaulan). Lingkungan sosial (pergaulan) yang paling menonjol sebagai faktor penyebap kenakalan remaja itu adalah yaitu karena ajakan teman sesama siswa serta keadaan lingkungan yang kurang memadai atau kurang bersih memacu anak melakukan kenakalan.

\section{Tindakan pencegahan yang dilakukan sekolah dalam menanggulangi kenakalan remaja yang disebapkan pengaruh media sosial}

Sekolah merupakan lembaga pendidikan formal yang secara sengaja dirancang untuk melaksanakan pendidikan, dimana fungsinya diantaranya adalah untuk mempersiapkan anak didiknya sebagai individu, warga masyarakat, warga Negara, dan warga dunia dimasa depan yang berpengetahuan, berketerampilan, dan berkarakter. Sekolah yang demikianlah yang diharapkan mampu melaksanakan fungsi pendidikan secara optimal, yaitu membentuk anak didik menjadi pribadih utuh yang melandasi ahlak dan budi pekerti luhur. Untuk itulah perlu upaya sekolah dalam menanggulangi kenakalan siswa secara dini.

Kaitan tindakan pencegahan yang dilakukan oleh bapak selaku kepala sekolah SMA Negeri 1 Mauponggo dalam menanggulangi kenakalan remaja yang disebapkan oleh pengaruh media sosial, berdasarkan hasil wawancara dengan kepala sekolah yakni bapak Aloisius Anggi menjelaskan:

"Sosialisasi orang tua dan siswa agar bisa membimbing anak didik agar bisa terhindar dari pada penggunaan media sosial yang berlebihan, sehingga menyebapkan siswa menjadi nakal, maka dari itu harus ada kerja sama antara guru dan orang tua agar bisa mencegah hal-hal yang tidak baik yang dilakukan oleh anak didik tersebut". (Wawancara, 28 April 2018).

Tindakan pencegahan yang dilakukan sekolah dalam menanggulangi kenakalan remaja yang disebapkan oleh pengaruh media sosial di SMA Negeri 1 Mauponggo. Dalam hal ini sekolah selalu memprogramkan pembinaan bidang kesiswaan yang terintegrasi kedalam program sekolah, melakukan pengembangan komponen pendidikan karakter kedalam kurikulum sekolah, baik yang bersifat intrakurikuler maupun ekstrakurikuler.

Demikian pula penjelasan ibu Ananias Coo selaku guru PPKn menjelaskan:

"Tindakan pencegahan yang pernah dilakukan agar siswa tidak terpengaruh dengan media sosial yaitu dengan memberikan sebuah sosialisasi mengenai dampak negatif yang ditimbulkan oleh media sosial." (Wawancara, 1 Mei 2018)

Tindakan pencegahan yang dilakukan sekolah dalam menanggulangi kenakalan remaja yang disebapkan oleh pengaruh media sosial yaitu mensosialisasi terhadap siswa dan siswa itu agar lebih bijak dalam penggunaan media sosial, kaena media sosial bisa membuat diri siswa menjadi baik, dan bisa membuat diri siswa menjadi nakal. dan siswa harus lebih giat lagi dalam mengikuti proses belajar mengajar.

Menurut ibu Nur Asfur mengemukakan sebagai berilut :

"Adapun tindakan pencegahan yang pernah dilakukan khususnya dalam lingkungan sekolah ialah dengan mengumpulkan HP sebelum proses KBM (kegiatan belajar mengajar)". (Wawancara 8 Mei 2018)

Hal serupa juga dijelaskan oleh bapak Saiful selaku guru PAI mengenai denga tindakan pencegahan yang lakukan oleh bapak terhadap siswa agar tidak terpengaruh dengan adanya media sosial yang mengarahkanya kepada kenakalan remaja. Beliau mengungkapkan:

"Hal yang pernah dilakukan kami sebagai seorang guru untuk mencegah terkait dengan pengaruh media sosial ialah dengan memberikan sosialisasi akan dampak negatif yang ditimbulkan oleh media sosial tersebut. Menghimbau kepada siswa agar tidak membawa HP ke sekolah. Namun terkadang siswa juga tidak mau mengikuti anjuran. Sehingga ada sebagian siswa yang membawa HP ke sekolah". (Wawncara, 11 Mei 2018)

Selain itu, pihak sekolah tampaknya selalu berupaya untuk meningkatkan peran aktif komunitas sekolah (kepala sekolah, guru PPKn, guru Bahasa Indonesia, guru PAI, guru BK/BP, dan orang tua/wali siswa) dalam memeriksa hanphone yang dibawa oleh siswa, pemeriksaan dilakukan pada awal pembelajaran.

Menurut bapak Wildan selaku guru BK/BP, menjelaskan:

"Hal yang pernah dilakukan kami sebagai seorang guru untuk mencegah terkait dengan pengaruh media sosial ialah dengan memberikan sosialisasi akan dampak negatif yang ditimbulkan oleh media sosial tersebut. Menghimbau kepada siswa agar tidak membawa 
HP ke sekolah. Namun terkadang siswa juga tidak mau mengikuti anjuran. Sehingga ada sebagian siswa yang membawa HP ke sekolah". (wawancara 15 Mei 2018)

Untuk tindakan pencegahan kenakalan siswa kegiatan yang dilaksanakan adalah : (1) melaksanakan sosialisasi bersama orang tua siswa tentang peraturan tata tertib sekolah, (2) melaksanakan kegitan kegiatan yang bersifat ekstrakurikuler berbasis pendidikan karakter (pendidikan tentang nilai nilai sikap, moral dan perilaku) dengan melibatkan kepala sekolah, , guru PPKn, guru Bahasa Indonesia, guru PAI, guru BK/BP. Oleh karna itu upaya pencegahan itu sangat penting, dan kegiatan itu secara sistematis, berencana, dan terarah, untuk menjaga agar kenakalan itu tidak timbul.

\section{TEMUAN DAN DISKUSI}

Peran guru dalam membimbing peserta didik agar lebih bijak menggunakan situs jejaring sosial atau media sosial sangat dibutuhkan.hal ini menjadi penting dikarenakan pada saat ini hampir semua orang menggunakan media sosial sebagai kebutuhan seharihari. Oleh sebab itu sebagai calon seorang guru sudah semestinya kita mengetahui dan paham perkembangan yang dilalui setiap peserta didik.

Fenomena yang sedang marak sekarang ini adalah pesrta didik yang sering mengaplod segala sesuatu yang mereka rasakan melalui media sosial. Sebagai seorang guru tentuya sangat penting mengetahui sikap pasarta didik yang aktif bermain media sosial agar guru dapat mengontrol siswanya agar tidak menggunakan media sosial kejalan yang tidak baik (Negatif) dan mengupload hal hal yang tidak menguntungkan menjadi konsumsi publik. Pendamping guru kepada siswa yang bermain sosial media yaitu dengan mengontrolnya melalui sosial media juga, maksudnya guru memiliki media sosial yang siswa miliki sehingga segala sesuatu di media sosial dapat diketahuai guru dan dapat dikontrol dengan baik[16].

Mengenai dengan faktor penyebab kenakalan remaja melalui proses internalisasi diri yang keliru oleh anakanak remaja dalam menggunakan media sosial, dan menghadapi lingkungan di sekitarnya. Tingkah laku mereka merupakan reaksi yang salah satu irasional, yang terwujud dalam ketidak mampuan mereka untuk menggunakan media sosial dengan baik, sehingga siswa mudah terpengaruh oleh perkembangan dunia maya sehingga mereka kurang beradaptasi terhadap lingkungan sekitar. Selain itu kenakalan remaja disebabkan oleh faktor faktor dari luar itu sendiri. Mereka tentu nakal ada penyebabnya yang dimunculkan oleh keluarga, dan masyarakat[17].

Disamping faktor internal dari dalam diri siswa itu sendiri pengaruh lingkungan sosial dalam hal ini hubungan pergaulan antar siswa atau kawan kawan seperti ajakan bolos sekolah, tidak sekolah tanpa ada keterangan apapun dan mengguanakan media sosial yang tidak tepat pada sasarannya. Keinginan seseorang siswa untuk melakukan perbuatan yang tidak baik itu karena adanya suatu dorongan sosial atau terbentuk karna tuntutan pergaualan. Sikap pergaualan yang tidak baik ini dapat pula merupakan sumber atau faktor penyebab terjadinya kenakalan.

Oleh karena itu, dalam pencegahan kejahatan di media social perlu dilakukan penyaringan komunikasi pada media social, hal ini sejalan dengan hasil penelitian lainnya bahwa Computer Mediated Communication (CMC) Models memiliki impersonal, interpersonal dan hyperpersonal[18]. Ketiga pola ini terbangun dalam kasus love scam. Faktor sumber pesan (scammers) memiliki kontrol yang besar terhadap dirinya sendiri dan berada dalam pengaturan komunikasi dengan korban-korbannya yang sama sekali tidak tahu siapa sebenarnya mereka. Karena itu scammers umumnya mencoba menyampaikan unsur-unsur diri yang terbaik, termasuk kepribadian, prestasi, dan bahkan penampilan (foto) melalui saluran komunikasi internet. Penerima pesan (korban) yang sedang kesepian dan mencari jodoh biasanya langsung tersanjung dengan pesan cinta dan tanpa pikir panjang melakukan umpan balik. Komunikasi secara intens pun terjalin hingga korban terjerumus dan masuk perangkap penipuan dan kehilangan uang hingga ratusan juta rupiah.

\section{E. SIMPULAN DAN SARAN}

Berdasarkan paparan data dan pembahasan sebagaimana telah diuraikan pada bagian sebelumnya, maka hasil penelitian ini dapat disimpulkan bahwa peran guru dalam membimbing peserta didik agar lebih bijak lagi menggunakan situs jejaring sosial atau media sosial sangat dibutuhkan. Hal ini menjadi penting dikarenakan pada saat ini hampir semua orang menggunakan media sosial sebagai kebutuhan seharihari, termasuk siswa/siswi yang ada di SMA Negeri 1 Mauponggo. Oleh sebap itu, sebagai calon seorang guru sudah semestinya kita mengetahui dan paham perkembangan yang dilalui setiap peserta didik, dengan cara seperti ini siswa bisa terhindar dari pengeruh media sosial yang sudah merasuki pemikiran siswa untuk melakukan hal-hal yang negatif.

Peran guru juga akan senantiasa menggambarkan pola tingkah laku yang diharapkan dalam berbagai interaksinya, baik dengan siswa (yang terutama), sesame guru, maupun mengajar, dapat dipandang sebagai sentral bagi peranannya. Sebab baik disadari atau tidak bahwa sebagian dari waktu dan perhatian guru banyak dicurahkan untuk menggarap proses belajar mengajar dan berinteraksi dengan siswanya. Peran guru dalam proses belajar mengajar adalah guru sebagai pendidik, guru sebagai pengajar dan fasilitator, guru sebagai pembimbing, guru sebagai pengarah, guru sebagai pelatih, guru sebagai penilai, guru sebagi pemimpin, guru sebagai mediator, dan guru sebagai evaluator. 
Disarankan bagi sekolah untuk melakukan tindakan pencegahan terhadap siswa yang membawa HP di sekolah, peneliti lain untuk mengkaji peran guru dan masyarakat sekolah dalam menghadapi pengaruh media sosial terkait dengan kenakalan remaja pada aspek lain yang lebih mendalam.

\section{UCAPAN TERIMA KASIH}

Penulis mengucapkan terima kasih kepada pihak Universitas Muhammadiyah Mataram yang senantiasa memberikan saran, masukan, dan dana kepada penulis sehingga artikel ilmiah ini selesai dengan tepat waktu.

\section{DAFTAR RUJUKAN}

[1] S. B. Istiyanto, "Telepon Genggam Dan Perubahan Sosial Studi Kasus Dampak Negatif Media Komunikasi dan Informasi Bagi AnakAnak di Kelurahan Bobosan Purwokerto Kabupaten Banyumas," J. Komun. Ikat. Sarj. Komun. Indones., vol. 1, no. 1, pp. 58-63, 2016.

[2] J. W. Santrock, "Masa perkembangan anak," Jakarta: Salemba Humanika, 2011.

[3] K. Wardani, "Peran Guru Dalam Pendidikan Karakter Menurut Konsep Pendidikan Ki Hadjar Dewantara," in Proceeding of The 4th International Conference on Teacher Education; Join Conference UPI \&UPSI, 2010, pp. 8-10.

[4] D. I. Savitri and I. N. S. Degeng, "Peran Keluarga Dan Guru Dalam Membangun Karakter Dan Konsep Diri Siswa Broken Home Di Usia Sekolah Dasar," J. Pendidik. Teor. Penelitian, dan Pengemb., vol. 1, no. 5, pp. 861-864, 2016.

[5] T. Suharto, "Konsep Dasar Pendidikan Berbasis Masyarakat," Cakrawala Pendidik., no. 3, 2005.

[6] J. R. Situmorang, "Pemanfaatan internet sebagai new media dalam bidang politik, bisnis, pendidikan dan sosial budaya," J. Adm. Bisnis, vol. 8, no. 1, 2012.

[7] C. Su and N. Zakiah, "Persepsi dan penggunaan media sosial dari perspektif ibu bapa: Satu analisis kualitatif," J. Komunikasi, Malaysian $J$. Commun., vol. 30, 2014.

[8] Sugiyono, "Metode penelitian kombinasi (mixed methods)," Bandung Alf., 2015.

[9] P. Sugiyono, Metode Penelitian Kuantitatif, Kualitatif, dan R\&D. 2013.

[10] P. D. Sugiyono, "Metode Penelitian dan Pengembangan," Res. Dev. D, 2015.

[11] P. Sugiyono, "Dr. 2010," Metod. Penelit. Kuantitatif, Kualitatif, dan R\&D. Bandung CV Alf.

[12] L. J. Moleong, Metodologi penelitian. 1999.

[13] S. Nasution, Berbagai pendekatan dalam proses belajar dan mengajar. PT. Bina Aksara, 2000.

[14] K. G. Esterberg, "Qualitative methods in social research," 2002.

[15] M. B. Milles, "Huberman. 1984. Qualitative Data Analysis." London: Sage Publication.

[16] A. Sardiman, "M. 2014," Interak. Motiv. Belajar Mengajar.

[17] R. Aditya, "Pengaruh Media Sosial Instagram Terhadap Minat Fotografi Pada Komunitas
Fotografi Pekanbaru," J. Online Mhs. Bid. Ilmu Sos. dan Ilmu Polit., vol. 2, no. 2, pp. 1-14, 2015.

[18] C. Juditha, "Pola Komunikasi Dalam Cybercrime (Kasus Love Scams)," J. Penelit. dan Pengemb. Komun. dan Inform., vol. 6, no. 2, 2015. 